\title{
Campaigning by Human Branding: Associating with American Presidents
}

\author{
Neil Collins ${ }^{1,2}$ (D)
}

Received: 1 August 2020 / Accepted: 29 August 2020 / Published online: 8 September 2020

(c) Fudan University 2020

\begin{abstract}
Human branding has become an essential issue in political marketing. It is exemplified in the election of American Presidents. This paper examines the American experience to suggest a typology of human branding that may apply in both presidential and other political systems. It examines examples of presidential human brands from George Washington on but, given significant changes to electoral procedures, concentrates on first-time successful presidential candidates since 1901. The fourfold typology offers an interrelated set of ideal types that will augment the analysis of human branding. It is applied to presidents when they take up office rather than after serving. The typology draws on the source of primary brand association and relation to the core political system of each politician.
\end{abstract}

Keywords Human branding · Branding by association - US presidential elections · Typology $\cdot$ Political marketing

\section{Introduction}

For political scientists, presidential elections and primaries present analytically interesting issues of policy, representation, power broking and societal unrest through which to see various presidential bids. The clash of ideas is seldom more dramatically rehearsed than during the race to presidency. When observed through a "marketing" analytical lens, a fresh perspective exists that may help clarify complex situations. In such contests, the competition and outcomes between the parties and the candidates may be explained by the relative strategic positions they take up and how they communicate to the electorate. The marketing analysis offered here concentrates less on particular policy positions, but rather focuses on the place of the

Neil Collins

n.collins@ucc.ie

1 Political Science and International Relations, Nazarbayev University, Nur-Sultan, Kazakhstan

2 Department of Government and Politics, University College Cork (UCC), Cork T12 K8AF, Ireland 
candidates in the public's mind relative to their political rivals. In this analysis, politicians are seen as creating a brand by their perceived association with the social and political features that have meaning and symbolic value to sections of the electorate. It also suggests that this marketing outlook may offer insights into the dynamics of both contemporary and past US presidential elections.

This article applies the idea of human branding to construct a typology using the brand identity of US presidents. Further, it provides a post hoc segmentation approach to set out the relative market positions of the candidates in presidential elections starting from the early twentieth century. It also reviews previous contests to show that, despite not consciously marketing, all presidents leveraged their brand image.

In marketing, branding is an essential topic for research because "brand" is a core concept underpinning an understanding of customer value, market positioning, consumer experience and management performance (Speed et al. 2015). ${ }^{1}$ An increasingly significant aspect of political marketing research is the "human brand", described by Thomson (2006, p. 104) as "any well-known persona who is the subject of marketing communications efforts".

Branding is ultimately about forging a differentiating identity, for which people... or person-like qualities... are often used to manufacture. Periodically, individuals themselves become brands... and serve as the primary source of identity. Candidate brands are similar to the latter, where political leaders and their associations define the brand. (Parker 2012, p. 209)

This article attempts to finesse this idea by applying it in the context of American politics, suggesting a typology and examining it using the brand identity of US presidents. In doing so, it does not seek to reduce the significance of the holders of this office as democratic leaders but rather to refocus on some of the explanations for their electoral success. As Needham and Smith (2015, p. 1) say, "[p]olitical branding has gained increased attention within marketing and political science journals, highlighting the growing consensus that parties and politicians can usefully be conceptualised as brands".

Despite the long-established practice of branding, Winchester et al. (2016, p. 259) assert that an understanding of "branding philosophies and practices is still a gap in political marketing". The analysis presented here seeks in part to address this shortcoming by examining the case of American presidential candidates in order to arrive at an initial typology of relevant brand images.

Among other factors, this article will examine the role played in the brand creation of American presidents by their character or personality, ${ }^{2}$ social background, professional career and political profile. ${ }^{3}$ It will also attempt to gauge the relationship

\footnotetext{
1 Despite this, "[t]here is no consensus about how to define "brand", according to Jones and Bonevac (2013, p. 112).

${ }^{2}$ Character is assumed to be developed early in life but to be mutable, and personality is taken to be the superstructure of character. See Renshon (2013).

3 For a psychological typology, see Rubenzer et al. (2000).
} 
between human brands and an evolving party system. The typology developed aims to facilitate marketing analysis in other non-American political contests. The power of a typology arises from the ease with which cases can be accurately classified and the degree of insight that is generated by the differences between the ideal types. Accordingly, the paper seeks the simplest possible conceptual framework that yields useful results. It suggests that the brand association of politicians will be affected by two factors-one summarising their social or professional background and the other their relationship to the political system itself. In particular, the paper seeks to distinguish between those whose political capital derives primarily from a close association with central government and those whose associations are with other political structures.

The article will be restricted to brand image when first elected so that presidential performance is not relevant for the voter. Almost all presidents see their popularity decline in office. As Mueller (1985, p. 233) concluded, if a president aimed to buck this trend, "he should either (1) be Dwight David Eisenhower, or (2) resign the day after inauguration".

\section{Characteristics of the Political Marketing Context}

Political campaigns are analogous to the product development and launch process in the world of enterprise. Mauser (1983), however, highlights some important distinguishing factors:

- commercial markets typically support a large number of business firms, whereas most political systems tolerate only a small number of political parties;

- markets usually run virtually continuously, whereas elections are periodic; and

- political organisations are not motivated by the imperatives of profit.

On the other hand, the key similarity is choice between competing offers. In the case of political competition, the offer generally includes the party platform as well as its champion, though in the United States the eventual Republic or Democratic nominee is not as obliged as in other systems, to be true to the party message. As Glass (1985, p. 517) suggests:

In each presidential campaign much attention is focused on the personal attributes of the candidates. Even when the focus of the campaign appears to switch from personalities to issues, it is often what the issue reveals about "the man" rather than the issue itself which is in the spotlight.

In the American system, the candidate is relatively free to change policy positions. $\mathrm{He}$ is not compelled to agree with the Congressional party (Marland and Wagner 2020). The candidate may present policy change as responding to new circumstances or, as Volle (2015, p. 1) suggests, for electoral reasons. As Butler and Collins (1994, p. 22) put it, "[a] notable property of political marketing is that the "purchase' is alterable even in the post-purchase setting". 
For this reason, it is even more likely that American voters will rely on unchanging aspects of the offer before them, such as the candidate's brand image. As Wang (2013, p. 484) notes, "there has been a dramatic increase in the understanding of the...close link between emotion and political attitudes and behavior... strongly predict[ing] individual political preferences, evaluations of office-holder performance, and support for public policy and political action".

Given the complexity of a fully rational voting choice, it is not surprising that brand image offers an attractive heuristic path chosen by a broad range of voters: "The myth that the better educated are less concerned with personal attributes of presidential candidates than the less educated is simply that-a myth" (Glass 1985, p. 523).

More recent research may help to identify the personal attributes that are considered most important by voters. As Scammell (2014, p. 72) suggests: "Brand research is primarily qualitative, seeking of necessity to delve beneath the surface evidence of quantitative polling".

From the pioneering 1950s work of Campbell et al. onwards, it has been clear that "[p]erceptions of the personal qualities of candidates proved to be of critical importance for partisan turnover in the White House, overcoming evaluations of issues and social groups" (Norpoth 2009, p. 523). To draw on Holian and Prysby's (2014, pp. 5-6) research on candidate character traits in presidential elections, "perceptions of the personal traits of the candidates play an important role in presidential elections". Reviewing the literature, Holian and Prysby (p. 23) offer leadership, competence, integrity and empathy as the most often identified as relevant to voters' judgements.

Following Speed et al. (2015), the analysis here will examine the problem of brand authenticity in the context of American electoral competition. As in marketing more generally:

... authenticity is used to refer to the genuineness, reality or truth of something... Consumers experience authenticity differently and use a range of cues to evaluate the authenticity of an object, which may be based on their interest in, and knowledge of, a subject. (Napoli et al. 2014, p. 1091)

At several points in American history, the functions of the presidency have changed. The tenures of Andrew Jackson, Abraham Lincoln, Theodore Roosevelt and Franklin D. Roosevelt are often seen as turning points. For example, from the beginning of the New Deal and the end of the Second World War, the president's responsibilities for the economy became more prominent, though as Lynch (2002, p. 29) argues: "Government economic policy in the late nineteenth and early twentieth centuries did affect important blocs of voters - specifically farmers and industrial workersalbeit in different ways that government policy affects voters today".

The elements of the presidential brand may have altered in their salience but, it is argued here, there are significant continuities. Similarly, though brand is the focus here, there is no doubt that partisanship and ethnicity influence the individual elector to either cast their vote, even for candidates to whom they are not attracted, or to abstain. Similarly, the cleavages formed by the Civil War weighed more heavily than any brand association based, for example, on class or personality traits, for most 
presidential elections. Party allegiance is generally long term but "it can change under some circumstances. In particular, national crises have had large effects on the distribution of partisanship" (Lewis-Beck 2014, p. 401).

Such fundamental shifts are rare. Yet, even if brand considerations were overridden by the power of the dominant political cleavages, each successful presidential candidate seeks to project an image that will resonate with some or all sections of the electorate. Further, though their likely behaviour may be predictable, voters do make choices and their ultimate decision is influenced, in part, by the characteristics of the offer before them. As Michael Deaver, Ronald Reagan's campaign manager, said before the 2000 presidential election: "People are going to make their decision based on the impression a candidate makes more than anything else" (as cited in Boller 1999, p. 419).

Nevertheless, the voters' judgements will also be framed by economic and political circumstances such as unemployment, international tension and the moral climate of the time. The decision to vote is also influenced by a sense of social duty that is infrequently paralleled in the commercial world and which further erodes the usefulness of models of voting based simply on rationality, either by weighing policy advantage or potentially being the decisive player:

... instrumental benefit cannot explain why millions vote in elections that they can reasonably be expected to know are not close. This fact gives rise to a 'consumption' benefit from voting which includes the pleasure a person experiences of fulfilling her civic duty to vote and the avoidance of the potential displeasure of having failed to vote when it might have mattered. (Rogers et al. 2013, p. 91)

Though this article looks in detail at 19 of the most recently electorally successful politicians, it is not concerned with how history subsequently judged them (Holmes and Elder 1989). Also, the article assumes that brand influences voters and is reflected in the electoral outcome: "The effective electoral arenas for American presidential politics are the states, in which a candidate captures all the electoral votes for any state he wins, regardless of his margin of victory" (Silbey and Bogue 2015, p. 180).

Despite its American focus, however, this article is intended to contribute to the conceptual development of human branding in political marketing more generally. Following Speed et al. (2015), it will outline the particular characteristics of the political marketing context and the concept of branding through association in American politics.

\section{Human Branding in American Politics}

The 2016 presidential election in the United States offered exceptional issues for parties, pundits and public alike. Perhaps the most extraordinary topic was the rise of Donald J. Trump as the nominee of the Republican Party despite the opposition of the power brokers in that party. His election platform included many appeals to populist opinion that appalled most analysts but seemed to find favour with many 
sections of the electorate. Again in 2019/20, in the Democratic primaries, young voters responded enthusiastically to Bernie Sanders, who was perceived as radically left of centre and the oldest contestant. Distinctive personalities have always been important in American politics.

Washington's actual presence was almost guaranteed to trigger genuine public displays of expressive silence... a real person riding a great white horse - people reported not only that they were speechless, but also that they were able to read profound meaning in the man's face... they could see - even feel - for themselves the most inspiring aspects of the president's character. (Breen 2016, p. 127)

As Breen (2016, p. 73) suggests, the "iconic image... was the product of carefully crafted political theatre". It was designed to create the Washington brand that was fashioned for a largely illiterate electorate. As well as employing posters and cartoons, Washington's campaign staff "doled out hand-painted portraits and engraved buttons that supporters sewed onto their clothing" (Glassman 2015).

For reasons to do with the mechanics of voting (see Hale et al. 2015), this article will primarily cover only the elected presidents since $1901,{ }^{4}$ though the 1840 "Log Cabin Campaign" between William Henry Harrison and John Tyler represents something of a turning point in campaign tactics (Gunderson 1977). A rhetoric attack on Harrison by The Baltimore Republican greatly misjudged the public mood and seemed to denigrate the hardworking frontier community: "Give him a barrel of hard cider and a pension of two thousand a year, and... he will sit the remainder of his days in his log cabin" (as cited in Davies 2002, p. 14). Symbols and mock-ups of log cabins appeared everywhere and the Whig candidate won handsomely.

During the 1844 campaign, techniques used in the 1840's Log Cabin extravaganza were more widely applied and further refined - although "refined" is perhaps not the most appropriate word for the frenzied rallies, parades, "pollraisings", "musters", picnics and barbecues used to arouse mass enthusiasm.

(Benson 2015, p. 124)

The campaign became the touchstone for successful branding by association. As Brookes (2012) explains the trope: "to live up to a 'log cabin' ideal... candidates need to 'connect with majority values', showing that they experience 'common emotion with uncommon intensity",.

There is a plethora of presidential rankings. The majority of them seek to measure performance in office, often described as "greatness" (Nichols 2012). Most of them result from surveys of scholars or the American public but seldom engage with the discipline of marketing. The American presidency offers a particularly useful focus for research on the human brand because of the distinctive role of the person in the party organisation and the constitutional character of the office as the only nationally contested position. As Wattenberg (2016, p. 125) states, "American presidential

${ }^{4}$ Excluding vice-presidents who assumed office on the death or resignation of the incumbent. 
elections are inherently personal contests, as unlike in parliamentary systems, voters are able to cast a vote directly for the nation's chief executive".

There is also a great wealth of research on American elections to demonstrate that "voters use information shortcuts to electoral decisions by making inferences about candidates based on the candidate's social, political and demographic characteristics" (McDermott 2009, p. 606).

The popular nature of the presidential elections has changed significantly even though the electoral college system is still in place. In 1800, for example, members of the college were chosen by popular vote in just two states; by 1832, only South Carolina retained the old system. Similarly, by the 1820 s almost all adult white males could vote in nearly all states. The level of party organisation also changed to reflect this broadening participation and the broader impact of Jacksonian democracy. As early as 1828, Jackson's presidential campaign featured techniques of mass participation and symbols, such as hickory poles "to advertise 'Old Hickory", (Aldrich 1995, p. 101), the candidate's nickname and symbol of his military past. The Jackson campaign was focussed and pro-active. It was characterised by "deliberate image building and mythmaking and of skilful manipulation of public perception and popular opinion" (Heidler and Heidler 2018, p. 5)

Jackson was both rich and famous but he was able to position himself as the representative of the "common man" and their champion against the Washington elite. In 1824, he had received the most popular and electoral votes, though a majority of neither. John Quincy Adams became president following a vote in the House of Representatives. In recent elections, only George W. Bush and Donald Trump have become president without a majority in the popular vote, though Woodrow Wilson with $42 \%$ won because the Republican party vote was split.

A lot has been made of the changing technologies available to presidential candidates such as radio, television and the Internet. Here, the assumption is made that, whatever the means available, the brand projected is unaltered. As Schlozman, Verba, and Brady (2010, p. 489) speculate, the effect of the Internet may be not to raise political activity but instead to repackage it.

Nevertheless, it does make sense to suggest that the use of the media reflected the sensibilities of the period:

Candidates began to campaign for themselves in the middle decades of the $\left[19^{\text {th }}\right]$ century, with little of the damage that self-promotion had caused earlier. In the 1820s and 1830s, self-promotion was deemed about a badge of dishonor for any candidate. One Jacksonian stalwart expressed the common wisdom of the age when he noted that those with the 'lust for office' deserved no respect. (Baldasty 1992, p. 38)

After the 1850s, explicit campaigning became the norm, though candidates had brand images before then as well as prototype campaign managers. Even the bestknown non-campaigning presidential candidate of the nineteenth century, William McKinley, who ran in 1896, had previously been a vigorous congressional candidate. In the presidential election itself, his strategist Mark Hanna sought to portray him as "the advance agent of prosperity" (Deskins et al. 2010, p. 258) and the candidate gave speeches to all who turned up to his Ohio home. By the time of the 
McKinley "non-campaign", the political parties were themselves established and expensive organisations. 5

Similarly, while changes to the media landscape may not have changed the fundamentals of the brand, the near saturation news cover has given rise to what Tulis (1987, p. 18) called the "rhetorical presidency", a process of "active and continuous presidential leadership of popular opinion".

\section{Branding Through Association}

Brand association is taken here to be both positive and negative information related to a brand in a consumer's memory (Keller 1993). As French and Smith (2013, p. 1357) state, "brand information is recalled from memory by an 'activation' process when one association stimulates the recall of another, linked association".

For a sceptical political "customer", a candidate's association with positive images or ideals can be more important than overt promotional tactics. As Lilleker (2014, p. 199) suggests in a review of communications theory:

... many citizens across democracies will have low interest, or low involvement, in politics and so be likely to rely on the peripheral processing of political communications....it means that simple images, phrases and slogans come stored in the schema of the receiver, so forming associations.

This article proposes a branding typology to examine the electoral success of recent American presidents with particular reference to their childhood or early adult background, their professional career and political experience. For example, cowboy imagery, military background, public service record and family values will be assessed as signifiers relevant to holding presidential office. In relation to the childhood home especially, associations with rural, small town or farming images, which play an important role in the American cultural imagination, will be examined. As with charismatic leaders as understood in the psychological literature, references to their social background helps candidates associate themselves with "a collective's history and tradition, their own identification with followers, shared values and moral justifications, and so forth" (Emrich et al. 2001, p. 527).

Morreale (1996, p. 9) suggests that all presidential candidates fall into one of two categories depending on where they line up on the dual promise contained in America's core myth - the American Dream of rugged individualism and a caring and united nation:

... presidential candidates' images... typically emphasize one or other of the myths... They are wise and virtuous leaders whose unique talents enable them to rise above the people: or they are populist men of the people who are mere instruments of the popular will.

\footnotetext{
${ }^{5}$ The 1896 McKinley "non-campaign" cost $\$ 3,350,000$. See Davies (2002).
} 
The contrasting associations were neatly displayed in one of the closest races in recent time during which $\mathrm{Al}$ Gore was presented on his web site as "a candidate who appeared active by inter-acting with ordinary American citizens, dressing casually, and appearing in places like schools, restaurants, and kitchens... By contrast, Bush's images seemed to convey a dignified leader" (Verser and Wicks 2006, p. 194).

The analysis here does not take issue with this dichotomy but presents a wider set of associations by which candidates seek a brand. It also assumes that "effective campaigns coordinate images, commercials, news releases, and speeches in ways that will reinforce reoccurring themes of the candidates" (Verser and Wicks 2006, p. 182).

For purposes of this typology, the broad range of significant and positive brand associations will be sorted into two groups:
1. social; and
1. outsider; and
2. professional
2. insider

The two groups are treated as binary variables to form discrete categories.

As Critchlow (2015) observes: "Successful presidential candidates from the earliest days in American politics ran as outsiders and against the status quo".

Although as outline above, the analysis presented here does not cover incumbent presidents seeking another term but Washington experience is often a primary brand association. In all, 27 presidents have had experience in Congress-six in the Senate only, 12 in the House only and nine in both (Marchant-Shapiro 2015, p. 69). It can, however, be both an advantage and disadvantage. Trump, Eisenhower and Arthur were the last presidents not to hold federal or state-wide office but, even among other politicians, whether the key association is as a Washington insider or outside is significant. ${ }^{6}$ As Ambar (2014, p. 76) observes, "Washington insiders proved more electable to the presidency during periods of relative consensus, as was the case between 1945 and 1976".

The more turmoil, the better the chances for outsiders. According to MarchantShapiro (2015, p. 91), due to their pro-active role in the Populist Era:

... governors became increasingly more influential politically and increasingly more likely to become powerful contenders for the presidency. Today, it is commonplace to assume that service as the chief executive of a state is a good preparation for service as a national chief executive.

As Ambar (2014, p. 92) suggests of Reagan, Clinton and Bush, they were "equipped-unlike senators or vice presidents- to take office with the mandate of outsiders". So the prefix Governor, as opposed to Senator or Vice President, can have an impact by association though not inevitably. ${ }^{7}$

\footnotetext{
${ }^{6}$ Chester A. Arthur assumed the presidency on the death of Garfield in 1881. Not included in the analysis.

7 Though in the early decade having been Secretary of State seemed to confer an advantage on Buchanan, who was the last holder to become President.
} 
... in the 2008 American presidential election... Hillary Clinton [had] been in the public eye on the national level for a period of 16 years... Unlike Hillary, Barack Obama, the former senator from Illinois, with seven years in the Illinois state Senate and one term in the U.S. Senate, was a Washington outsider, starting from scratch. (Ilie 2009, p. 548)

Similarly, in 1979, "Jimmy Carter, a relatively unknown outsider who had served one term as governor of Georgia and before that as a state senator in Georgia, won the Democratic nomination [and] went on to defeat incumbent president, Gerald Ford" (Jackson 2014, p. 94).

Richard Nixon's time in the national limelight was surpassed only by John Quincy Adams and he was nominated for national office by his party on five occasions. He nevertheless defeated the incumbent vice president in 1968 at a time of great national turmoil in part by spanning the divide. The categories insider and outsider will, therefore, need to reflect the dominant brand association rather than the formal titles (see King 2002). Nevertheless:

During the 20th century, the stature of vice presidential candidates improved. This could be attributed to changes in campaigning style, as well as changes in the role of the media in elections. As vice presidents began to actively campaign during the general election, they became known to the electorate and were better able to build their own constituency. (Marchant-Shapiro 2015, p. 49)

In the case of vice presidents who finished out their predecessors' terms, since 1901 only Theodore Roosevelt, Calvin Coolidge, Harry Truman and Lyndon Johnson were successful presidential candidates at the subsequent election. Of these, Johnson was the most clearly associated with the effective management of Washington. As Goodwin $(2015$, np.) suggests, he "played a dominant role... in transforming opportunity into achievement... the perception of Johnson-one that was accurate and that he encouraged-[was] as the gargantuan manipulator, the tireless practitioner of political skills".

Similarly, "the [George W.] Bush Web site presented the candidate as a professional public servant ready for leadership" (Verser and Wicks 2006, p. 189). William Taft, who seems to have found electioneering a real chore, also presented himself as the competent administrator "perfecting the machinery" (Lurie 2011, p. 83). Coolidge also presented the image of an insider best suited to running Washington efficiently. Voters were urged to "keep cool with Coolidge" (Boller 1999, p. 216). It is difficult for a vice president-cum-candidate to avoid association with the previous regime be that an advantage or burden.

The category social is taken to incorporate the brand appeal of a "humble background". This may be set within various narratives but triumphing over social disadvantage to achieve success is a common form of brand by association in America. For example, candidates Reagan and Obama appealed to different demographics, but their brand referenced a common theme of overcoming challenging family 
circumstances. The social category is also taken to encompass the "log cabin", 8 working class, small town and rural associations of successful presidential candidates. Of the Trumans, Donovan (1996, p. 146) suggests that on arrival, "[i]n contrast to the aristocratic Roosevelts, they imparted the flavor of small-town life to the White House".

So, for example, Harding was owner/publisher of a small-town newspaper in his native Ohio. Given the low reputation he now enjoys, it is worth noting that Harding was seen on election as 'a 'regular guy' - culturally distinct from such elitists, bluebloods, and academics as Franklin Roosevelt and Woodrow Wilson-a representative of American small-town masculinity" (Fine 1996, p. 1171). The "regular guy" image can be enhanced even by an apparent lack of rhetorical skill. Thus, for example, in 2004, candidate Bush's apparent trouble with language enhanced his popularity relative to the more eloquent and grammatically correct John Kerry.

Infrequently, the big city social background is seen as an asset with which to have your brand associated but:

Michael Dukakis [unsuccessful candidate, 1988] is one of the only candidates who makes a virtue out of coming from East Coast suburb, and who fails to pay tribute to America's heartland. In his [campaign] film, his cousin Olympia Dukakis takes viewers on a tour of Brookline, one of Boston's wealthy areas.

The image lacks mythic resonance. (Morreale 1996, p. 9)

Much more common in the campaign films, the genre of which candidates have complete control, are references to evoke "the agrarian myth that equates virtue with the land" (Morreale 1996, p. 9). In relation to the common touch, Democratic candidates have, at least since FDR, enjoyed the advantage as their party "still enjoys a groundswell of good feeling for favoring the 'common man,' 'little people,' 'working people,' the 'poor,' and the 'needy,' whereas the Republican Party is chastised for being in bed with 'big business,' the 'rich,' the 'upper class,' etc." (Norpoth 2009, p. 525). This advantage has been reduced somewhat by Trump's championing of the "brand of aggressive anti-elite and ethno-nationalist politics" (Pierson 2017).

Another aspect of branding by association categorised here as social is that of family values. Obviously, in the American context, family values are often assumed to be more firmly rooted in small town or rural contexts, but they are also appealed to more directly. Thus, for example: "Pictures of the young and attractive John F. Kennedy family contributed to the presumption on the part of the audience that the former president represented family values" (Verser and Wicks 2006, p. 182).

The family values theme was given something of a twist by Bill Clinton in that his "man of the people" stature was strengthened by his standing up for his mother and younger brother against his alcoholic father. Herbert Hoover, on the other hand, always hid his "emotionally and materially insecure childhood" while exaggerating his business and technical success (Wilson 1992, p. 15).

As Norpoth (2009, p. 529) states: "Without the test of the office, the challenger finds it nearly impossible to impress the public [on the issue of leadership] unless

\footnotetext{
8 James Garfield was the last president to live in a log cabin. See Feldman (2005).
} 
he has proven his leadership ability in a non-political career". The professional category is primarily taken to cover those whose brand is associated with success in a non-political arena. Coolidge (1925) famously said to have remarked that "the chief business of the American people is business". Success in business suggests to some voters that similar talents would be usefully applied to politics. As a New York Times commentary on a 2016 primary candidate with significant business success summarises the association, "the American dream still holds sway... In general, Americans, even those with few means, end up aligning themselves with the wealthy in the hope that they, too, will eventually get rich" (Covert 2016).

The brand association with business as a profession does not imply eschewing public service, rather it is about being viewed as not primarily a politician. So Wilson (1992, p. 118) writes of Hoover:

He projected an image of service, efficiency, morality, and prosperity... It was an image that will serve Hoover well in the presidential election of $1928 \ldots$ Hoover... a self-effacing ideologue... perfected the systematic administrative use of publicity and then used it to popularise the progressive ideal of the nonpartisan manager of government.

Twenty-five presidents have had legal qualifications, including 10 of the last 20, but few have leveraged this profession as a brand association (Gross 2009). John Adams, Rutherford B. Hayes and Benjamin Harrison are among the most notable lawyer-presidents in terms of brand image but none are in the group analysed here. In contrast, though "military voters have rarely had much impact in swaying elections" (Inbody 2016, p. 156), a professional background in the military can be a major branding clue for a candidate. Clearly, George Washington's brand image is as a successful military leader but others, such as Andrew Jackson, Zachary Taylor and Ulysses S. Grant, also became president being associated with professional military success. In the post-1901 group, Theodore Roosevelt and Dwight D. Eisenhower also used their military fame to establish their brands. It is not entirely clear, however, whether the favourable association is with rank or perceived leadership qualities: "as Eisenhower's case indicates, military service all by itself conveys little advantage with the American electorate" (Norpoth 2009, p. 528). For John F. Kennedy and George H. W. Bush their military decorations supplement other branding by association.

Successful businesspeople have increasingly entered politics in recent years. They point to their private sector success as evidence of their ability and argue that their skills are transferable to high office. Harding, Hoover, Bush $\mathrm{Sr}$ and most recently Trump used their professional achievements in business to strengthen their brand.

Because almost all the presidents were supported by a political party, they are not what Speed and Butler (2011) term "free standing human brands". Only Washington, John Tyler and Andrew Johnson were independents and the latter two were not elected to the presidency. Only exceptionally and early on does the president predate the party. The president's association with his party is, therefore, a crucial element of his success. So, not even former presidents Millard Fillmore and Theodore Roosevelt, with substantial appeal, could succeed as a "third party" candidate. Given the group in this analysis, there is no incumbency advantage to be taken into 
account. Nevertheless, the dominant characteristics of the party system at the time of their election are clearly an influence on which brands by association are likely to bring success.

Simply by being elected, the individuals who held the position of President of the United States were successful to some degree in establishing a brand image. Of course historical circumstances, the quality of their opponents and other factors influenced their success.

Though superficially a persistently two-party system, the competitive characteristics of American electoral politics are constantly changing. To ease comparison, however, this article adapts the six-category "party system" periodisation developed from Chambers and Burnham's (1967) edited volume by adding one and beginning at number four. Though Washington himself had opposed the development, the first party system revolved around factions in his own administration led by Hamilton and Jefferson. The Jeffersonian group, which argued for states' rights, gained the ascendancy until the 1820 s when it was challenged in what is now characterised as the second party system by the emerging Democratic Party. The opposition provided by the Whigs finally descended in factionalism and the third party system is taken to date from 1860 and was dominated by the consequences of the Civil War. In very broad terms, this resulted in the Democrats dominating the South and some of the major cities while the Republicans were in the ascendancy elsewhere.

For the purpose of this article, the election of 1896 is taken as the turning point for the next significant realignment of American party system, ${ }^{9}$ which broadly characterised politics until 1932. The Great Depression and the election of Franklin D. Roosevelt ushered in what is defined as the fifth party system, which is marked by the strong support of the Democratic Party from ethnically and economically marginalised groups. This system can be taken to have ended in 1968 when it gave way to the last period in this rough chronological guide. The sixth party system has seen the Republican Party become dominant in the South, rural areas and suburbs; while the Democratic Party resembles a coalition of African Americans, Hispanics and white urban progressives. The Reagan presidency is seen as affirming the change: "What makes the sixth party system unique is that for the first time in American history, there were decisive factional shifts within both major parties almost simultaneously, resulting in an almost un-American ideological polarisation between the parties" (Paulson 2015, p. 89).

The party system classification contextualises the standard descriptions of presidential elections derived from Key in his classic study and simplified here as maintaining, deviating and realigning. Thus, for example, the election of Woodrow Wilson in 1912 is seen as "deviating" from the pattern of Republican successes established in 1896. Wilson took advantage of a split in the Republican Party between incumbent President Taft and his predecessor Theodore Roosevelt. Republican hegemony was restored with Harding in 1920. A realignment was

\footnotetext{
9 "A durable and substantial shift in the parties' national electoral balance of power" as defined in Campbell (2006, p. 361).
} 
signalled by the success of FDR in 1932. Brewer and Maisel (2020, p. 41) point to the current debate among analysts:

In the wake of Donald Trump's 2016 presidential victory, there is now strengthening debate as to whether we are entering a new party system as Trump fundamentally reshapes the Republican Party and the Democratic Party responds and evolves as well.

They conclude that it is too early to tell.

The duopolistic features of party competition in America add to the complications of branding by association. Because they offer:

... limited channels for the expression of multiple social identities, the Democratic Party became a big tent for constituencies that might remain separate in multiparty systems while the Republican Party incorporated nationalist elements, which become far-right parties elsewhere, under a banner of conservative ideology. (Grossmann and Hopkins 2016, p. 135)

Nevertheless, the politics in each of the periods favoured different brands by association. So, for instance, if the parties are more polarised at elite level in the sixth party system, it may favour the outsider. For as Kuo and McCarty (2015, p. 54) point out, "since the 1970 s, ideological divisions have increased polarization between the Republican and Democratic parties... Congress has become increasingly unproductive... Public trust in democratic institutions has declined considerably, and partisanship in the electorate [has] exacerbated polarization in national politics".

The promise to tackle the problems "inside the Belt Way" could be a winner with the non-Washington candidate: "This critique partisanship is one thing that Barack Obama and his challenger, John McCain, agreed on in the 2008 campaign. Each promised to defang the poisonous partisanship in Washington and seek bipartisan solutions to the nation's problems" (Jackson 2014, p. 94).

The 2008 election was the first since 1952 in which neither candidate was president nor vice president. In 2016, one of the two candidates was distinctly outside the Washington milieu:

One, a former senator, former secretary of state, a former candidate for president, the spouse of a former president, and the heir apparent to the outgoing two-term president, was the embodiment of the very political establishment that populist uprisings rail against. The other candidate... wasn't. (Schier 2017, p. 3)

In seeking to identify the President of the United States according to their brand, this article does not suggest that each president can only be associated with one brand. Indeed, it is likely that individual segments of the market associated each individual with differing images. As Newman (1994, p. 71) puts it:

... political images do not exist apart from the political objects (or their symbolic surrogates) that stimulate political thoughts, feelings, and inclinations... [A] candidate's image consists of how voters perceive him, sections based 
Table 1 Source of primary brand

\begin{tabular}{lll}
\hline & \multicolumn{2}{l}{ Relation to core political system } \\
\cline { 2 - 3 } & Insider & Outsider \\
\hline $\begin{array}{lll}\text { Source of primary brand association } \\
\text { Derived from social factors }\end{array}$ & Champion & Challenger \\
& Empathy: high; credibility & $\begin{array}{c}\text { Empathy: high; credibility } \\
\text { varies }\end{array}$ \\
Derived from professional factors & Counsel & Combatant \\
& Empathy: varies; credibility & $\begin{array}{c}\text { Empathy: varies; cred- } \\
\text { ibility high }\end{array}$ \\
\hline
\end{tabular}

upon both the subjective appraisals made by the voters and the messages utterances, attributes, qualities, etc. transmitted by the candidates.

It is also not suggested that the brand of each politician was their most obvious characteristic. So, for example, Kennedy was the first Catholic president but this was not an essential part of his brand image. ${ }^{10}$ Referring to that brand image, O'Brien (2014, p. 82) suggests that "Kennedy retained an aura of youthfulness, now enhanced by the quality of maturity and its associated experience, wisdom and judgement. Pictures of Kennedy with his wife Jacqueline and two children promote the devoted husband, father and all-round family man".

Similarly, we are not suggesting that each president consciously cultivated brand but by habitually using references to his background, profession, personal traits, etc., he may become associated with a particular brand image. Further, we are not accepting as the basis of the brand ascribed social class along the lines employed by Pessen (1984). In the Pessen analysis, presidential stratification based on classbased criteria shows that the more plebeian the individual the less likely they are to become America's chief executive. This may be true and would certainly resonate with other political systems but for the human brand analysis class background is an insufficient criterion. Thus, for example, Van Buren's background was very modest but he projected a more affluent image and, in his later life, he became a "country gentleman": "It was a pleasant, comfortable life and with personal property and real estate worth as much as $\$ 200,000$, Van Buren could well afford to live the life of a country gentleman" (Cole 2014, p. 382). Nevertheless, to provide useful analytical characterisations, it is suggested that some brand associations are dominant despite factual realities.

Juxtaposing the two sets of brand descriptor defines four ideal types (see Table 1). To illustrate the differences between the resulting types, the paper highlights two variables on which significant differences are expected that affect the effectiveness of the human brand:

\footnotetext{
10 Kennedy did benefit from the voters of Catholics who normally supported Republicans but this was outweighed by anti-Catholic support for Nixon. See Polsby et al. (2008, p. 25).
} 
- empathy - the level of social association; and,

- credibility - the level of competence associated with the person.

In this schema, the "champion" is an insider whose social associations engender trust and whose record lends credibility. So, for example, as his vice president, Charles G. Dawes, wrote: "The popularity of Coolidge, notwithstanding the opposition he has encountered from a Congress nominally Republican, is due to the fact that he, not it, best understood the people and they him" (as cited in Fleser 1990, p. $51)$.

The "challenger" may be similarly admired as reflecting the values of an important constituency but his credibility based on having worked the political system of Washington may be questionable. Often their political experience is outside the mainstream and difficult for most voters to assess. As Winter (1998, p. 370) suggests, based on his analysis of his speeches, Clinton's appeal was based on his "high goals and aspirations, tinged with warmth and compassion. But [with] all his experience as governor of Arkansas, he might not be comfortable or effective in the quicksands of Washington federal politics".

The "counsel" draws strength from the presumption of credibility and being associated with achievement in his profession, even if that profession is essentially long-standing political office. He may not enjoy as much social empathy but he is expected to achieve policy goals: "Nixon sought to close the growing gap between the elites and ordinary people. Typically, he tailored his policies to left-leaning opinion leaders while crafting his rhetoric to propitiate the right-leaning 'silent majority"' (Barone 1999, p. 24).

To be a "combatant", the successful candidate appeals on the basis of assumed professional standing but being untainted by strong association with the central government. So, for example, Norpoth (2009, p. 527) suggests that:

A detailed breakdown of favorable references [in opinion surveys] to Eisenhower... points to some explanations... war hero, above all, with experience, a reputation for both leadership and honesty... This was a rare mix of qualities, and all of it acquired before the candidate's first day in the White House.

The strength of the categories is dependent on their ability to offer insights into the use of branding by association as applied to politicians. Below, US presidents are assigned their category according to their brand at the time of their first election to office (Table 2).

The assigning of presidents to the categories above results in some unlikely bedfellows. It is important to remember, however, that the analysis looks at the individual's brand on the day of taking office for the first time. Thus, for example, Trump and Obama are both seen as outsiders though their degree of distance from the "swamp" varied. At his inauguration, Trump (2017) declared: "a small group in our Nation's Capital has reaped the rewards of Government while the people have borne the cost". Righting the imbalance of power was also promised by Obama (2009): "our time of standing pat, of protecting narrow interests and putting off unpleasant 
Table 2 Presidential categories

\begin{tabular}{llc}
\hline & \multicolumn{2}{l}{ Relation to core political system } \\
\cline { 3 - 3 } & Insider & Outsider \\
\hline Source of primary brand association & & Challenger \\
Derived from social factors & Champion & Carter \\
& Coolidge & Clinton \\
& Harding & FDR \\
Kennedy & Obama \\
Derived from professional factors & & Reagan \\
& Counsel & Combatant \\
& Bush Sr & Bush Jr \\
& Johnson & Eisenhower \\
& Nixon & Hoover \\
& T. Roosevelt & Trump \\
& Taft & Wilson \\
\hline
\end{tabular}

decisions - that time has surely passed". One promised to "remake America", the other to "make America great again".

\section{Conclusions}

The typology offered here is based on a longitudinal study. It reflects the notion that voters, like customers, make choices based not on detailed knowledge but broad understandings of the offers being made. The brand is a coping mechanism to facilitate complex decisions. In the cases examined, brand characteristics allow judgements to be made based on which social cleavages are most pressing to the particular voter. The analysis above focusses not on specific policies but rather how the electorate imagine a particular candidate relative to his opponents. The brand matters in elections and it is conditioned by associations among the electorate.

Electioneering has evolved. The sophisticated, research-driven, data-based intelligence now driving campaign direction and decision-making is, in one sense, a long way from earlier campaign strategies. But, in another way, the fundamentals are the same. A value judgement informed by personal circumstance and social position is translated into a decision to vote for a candidate or to abstain. The intellectual capacities and constraints of voters are unchanged. The mechanics of the electoral system will condition the process of voting and the ability to express a range of preference. Nevertheless, on the day of an election, the voter is sovereign.

Though this analysis primarily addresses a marketing and political science audience, its starting point is confirmed by other research. In their anthropological study, Lempert and Silverstein (2012) also suggest that presidential campaigns 
are essentially more about a candidate's brand than the issues debated. For them, the quantity of material in the public arena during presidential campaigns militates against rational discourse. The psychology of voting has similarly informed the dominant model used by political science since the 1960s (Steenbergen 2010; McDermott 2009).

The human branding literature relied upon here does not radically question the analysis offered by other disciplines though, like them, it sits incongruously with democratic rhetoric. It also offers similarities between candidates in terms of brand that may seem counter-intuitive in the popular narrative suggesting, as it does, the same category for Reagan and Obama or Nixon and Johnson. Though some analysts may disagree with the position assigned to individual presidents, the article hopes to offer a heuristically useful typology of a kind that may be developed to allow comparisons between not only American but also other presidential systems.

The current rise in the influence of populism has focussed increasing attention on the head of government as the nation's leader in many countries with different institutional characters. The COVID-19 pandemic also emphasised the role of the political leader in the presentation and coordination of the response to a definite emergency. The personal brand of individual politicians is likely to become even more critical at the next round of elections as people reward their champions or flock to the challenger.

\section{References}

Aldrich, J.H. 1995. Why Parties?: The Origin and Transformation of Political Parties in America. Chicago, IL: University of Chicago Press.

Ambar, S.M. 2014. The Rise of Sunbelt Governors: Conservative Outsiders in the White House. Presidential Studies Quarterly 44(1): 72-94.

Baldasty, G.J. 1992. The Commercialization of News in the Nineteenth Century. Madison, WI: University of Wisconsin Press.

Barone, M. 1999. Nixon's America. US News and World Report, 20-27.

Benson, L. 2015. The Concept of Jacksonian Democracy: New York as a Test Case. Princeton, NJ: Princeton University Press.

Boller, P.F. 1999. Presidential Campaigns: From George Washington to George W. Bush. Oxford: Oxford University Press.

Breen, T.H. 2016. George Washington's Journey: The President Forges a New Nation. New York, NY: Simon and Schuster.

Brewer, M.D., and L.S. Maisel. 2020. Parties and Elections in America: The Electoral Process. London: Rowman \& Littlefield.

Brookes, S. 2012. The Art of the Campaign Gaffe: What We Learn When Candidates Stuff Up. The Conversation. Retrieved December 10, 2019 from https://theconversation.com/the-art-of-the-campaigngaffe-what-we-learn-when-candidates-stuff-up-9982.

Butler, P., and N. Collins. 1994. Political Marketing: Structure and Process. European Journal of Marketing 28(1): 19-34.

Campbell, J.E. 2006. Party Systems and Realignments in the United States, 1868-2004. Social Science History 30(3): 359-386.

Chambers, W.N., and W.D. Burnham (eds.). 1967. The American Party Systems: Stages of Political Development. Oxford: Oxford University Press.

Cole, D.B. 2014. Martin van Buren and the American Political System. Princeton, NJ: Princeton University Press. 
Coolidge, C. 1925. Address to the American Society of Newspaper Editors, Washington, D.C. The American Presidency Project. UC Santa Barbara. Retrieved 17 February, 2016 from http://www.presi dency.ucsb.edu/ws/?pid=24180.

Covert, B. 2016. Whose American Dream Flies? New York Times.

Critchlow, D. 2015. Hillary Clinton's Problem: She Can't Run Against Washington. The Conversation. https://theconversation.com/hillary-clintons-problem-she-cant-run-against-washington-45128.

Davies, P.J. 2002. The Material Culture of US Elections. Journal of Political Marketing 1(2-3): 9-24.

Deskins, D.R., H. Walton, and S.C. Puckett. 2010. Presidential Elections, 1789-2008: County, State, and National Mapping of Election Data. Ann Arbor, MI: University of Michigan Press.

Donovan, R.J. 1996. Conflict and Crisis: The Presidency of Harry S. Truman, 1945-1948. Columbia, MO: University of Missouri Press.

Emrich, C.G., H.H. Brower, J.M. Feldman, and H. Garland. 2001. Images in Words: Presidential Rhetoric, Charisma, and Greatness. Administrative Science Quarterly 46(3): 527-555.

Feldman, R.T. 2005. James Garfield. Minneapolis, MN: Twenty-First Century Books.

Fine, G.A. 1996. Reputational Entrepreneurs and the Memory of Incompetence: Melting Supporters, Partisan Warriors, and Images of President Harding. American Journal of Sociology 101(5): 1159-1193.

Fleser, A.F. 1990. A Rhetorical Study of the Speaking of Calvin Coolidge. New York, NY: Edwin Mellen Press.

French, A., and G. Smith. 2013. Measuring Brand Association Strength: A Consumer Based Brand Equity Approach. European Journal of Marketing 47(8): 1356-1367.

Glass, D. 1985. Presidential Candidates: Who Focuses on Their Personal Attributes? Public Opinion Quarterly 49(4): 517-534.

Glassman, E.T. 2015. The Branding of an American President. The Conversation. Retrieved May 24, 2016 from http://theconversation.com/the-branding-of-an-american-president-40451.

Goodwin, D.K. 2015. Lyndon Johnson and the American Dream. New York, NY: Open Road Media.

Gross, N. 2009. America's Lawyer-Presidents: From Law Office to Oval Office. Chicago, IL: ABA Museum of Law.

Grossmann, M., and D.A. Hopkins. 2016. Ideological Republicans and Group Interest Democrats: The Asymmetry of American Party Politics. New York, NY: Oxford University Press.

Gunderson, R.G. 1977. The Log-Cabin Campaign. Westport, CT: Greenwood Press.

Hale, K., R. Montjoy, and M. Brown. 2015. Administering Elections: How American Elections Work. Basingstoke: Palgrave Macmillan.

Heidler, D.S., and J.T. Heidler. 2018. The Rise of Andrew Jackson: Myth, Manipulation, and the Making of Modern Politics. New York, NY: Basic.

Holian, D.B., and C.L. Prysby. 2014. Candidate Character Traits in Presidential Elections. London: Routledge.

Holmes, J.E., and R.E. Elder. 1989. Our Best and Worst Presidents: Some Possible Reasons for Perceived Performance. Presidential Studies Quarterly 19(3): 529-557.

Ilie, C. 2009. Talking the Talk, Walking the Walk: Candidate Profiles in Election Campaign Interviews. In Proceedings of the IADA Workshop Word Meaning in Argumentative Dialogue, vol. II, ed. G. Gobber, S. Cantarini, S. Cigada, M.C. Gatti, and S. Gilardoni. Milan: Università Cattolica.

Inbody, D.S. 2016. The Soldier Votes: Wall, Politics, and the Ballot in America. Basingstoke: Palgrave Macmillan.

Jackson, J.S. 2014. The American Political Party System: Continuity and Change Over Ten Presidential Elections. Washington, DC: Brookings Institution Press.

Jones, C., and D. Bonevac. 2013. An Evolved Definition of the Term 'Brand': Why Branding Has a Branding Problem. Journal of Brand Strategy 2(2): 112-120.

Keller, K.L. 1993. Conceptualizing, Measuring, and Managing Customer-Based Brand Equity. Journal of Marketing 57(1): 1-22.

King, A. 2002. The Outsider as Political Leader: The Case of Margaret Thatcher. British Journal of Political Science 32(3): 435-454.

Kuo, D., and N. McCarty. 2015. Democracy in America, 2015. Global Policy 6(S1): 49-55.

Lempert, M., and M. Silverstein. 2012. Creatures of Politics: Media, Message and the American Presidency. Bloomington, IN: Indiana University Press.

Lewis-Beck, M.S. 2014. The American Voter Revisited. Ann Arbor, MI: University of Michigan Press.

Lilleker, D.G. 2014. Political Communication and Cognition. Basingstoke: Palgrave Macmillan. 
Lurie, J. 2011. William Howard Taft: The Travails of a Progressive Conservative. Cambridge: Cambridge University Press.

Lynch, G.P. 2002. US Presidential Elections in the 19th Century: Why Culture and the Economy Both Mattered. Polity 35(1): 29-50.

Marchant-Shapiro, T. 2015. Professional Pathways to the Presidency. Basingstoke: Palgrave Macmillan.

Marland, A., and A. Wagner. 2020. Scripted Messengers: How Party Discipline and Branding Turn Election Candidates and Legislators into Brand Ambassadors. Journal of Political Marketing 19(1-2): 54-73.

Mauser, G.A. 1983. Political Marketing: An Approach to Campaign Strategy. Santa Barbara, CA: Praeger.

McDermott, M.L. 2009. Voting for Myself: Candidate and Voter Group Associations Over Time. Electoral Studies 28(4): 606-614.

Morreale, J. 1996. Playing Politics: Mythical Portraiture in Presidential Campaign Film. Visual Communication Quarterly 3(1): 8-12.

Mueller, J.E. 1985. War, Presidents, and Public Opinion. Lanham, MD: University Press of America.

Napoli, J., S.J. Dickinson, M.B. Beverland, and F. Farrelly. 2014. Measuring Consumer-Based Brand Authenticity. Journal of Business Research 67(6): 1090-1098.

Needham, C., and G. Smith. 2015. Introduction: Political Branding. Journal of Political Marketing 14(12): $1-6$.

Newman, B. 1994. The Marketing of the President: Political Marketing as Campaign Strategy. London: Sage.

Nichols, C. 2012. The Presidential Ranking Game: Critical Review and Some New Discoveries. Presidential Studies Quarterly 42(2): 275-299.

Norpoth, H. 2009. From Eisenhower to Bush: Perceptions of Candidates and Parties. Electoral Studies 28(4): 523-532.

O'Brien, D. 2014. Classical Masculinity and the Spectacular Body on Film: The Mighty Sons of Hercules. Basingstoke: Palgrave Macmillan.

Obama, B. 2009. Obama's Inaugural Address: The Full Text. Time. Retrieved December 12, 2019 from http://content.time.com/time/politics/article/0,8599,1872715-2,00.html.

Parker, B.T. 2012. Candidate Brand Equity Valuation: A Comparison of U.S. Presidential Candidates During the 2008 Primary Election Campaign. Journal of Political Marketing 11(3): 208-230.

Paulson, A.C. 2015. The "Invisible Primary" Becomes Visible: The Importance of the 2008 Presidential Nominations, Start to Finish. In Winning the Presidency 2008, ed. W.J. Crotty, 87-109. London: Routledge.

Pessen, E. 1984. The Log Cabin Myth: The Social Backgrounds of the Presidents. New Haven, CT: Yale University Press.

Pierson, P. 2017. American Hybrid: Donald Trump and the Strange Merger of Populism and Plutocracy. British Journal of Sociology 68(S1): S105-S119. https://doi.org/10.1111/1468-4446.12323.

Polsby, N.W., A.B. Wildavsky, and D.A. Hopkins. 2008. Presidential Elections: Strategies and Structures of American Politics. Lanham, MD: Rowman \& Littlefield.

Renshon, S.A. 2013. The Psychological Assessment of Presidential Candidates. London: Routledge.

Rogers, T., C.R. Fox, and A.S. Gerber. 2013. Rethinking Why People Vote: Voting as Dynamic Social Expression. In The Behavioral Foundations of Public Policy, ed. E. Shafir, 91-107. Princeton, NJ: Princeton University Press.

Rubenzer, S.J., T.R. Faschingbauer, and D.S. Ones. 2000. Assessing the US Presidents Using the Revised NEO Personality Inventory. Assessment 7(4): 403-420.

Scammell, M. 2014. Consumer Democracy: The Marketing of Politics. Cambridge: Cambridge University Press.

Schier, S.E. 2017. The Trump Presidency: Outsider in the Oval Office. London: Rowman \& Littlefield.

Schlozman, K.L., S. Verba, and H.E. Brady. 2010. Weapon of the Strong? Participatory Inequality and the Internet. Perspectives on Politics 8(2): 487-509.

Silbey, J.H., and A.G. Bogue. 2015. The History of American Electoral Behavior. Princeton, NJ: Princeton University Press.

Speed, R. \& Butler, P. 2011. Towards a Typology of Human Brand-Organisation Relationships. In Proceedings of Academy of Marketing Annual Conference. Liverpool: University of Liverpool.

Speed, R., P. Butler, and N. Collins. 2015. Human Branding in Political Marketing: Applying Contemporary Branding Thought to Political Parties and Their Leaders. Journal of Political Marketing 14(1-2): 129-151. 
Steenbergen, M.R. 2010. The New Political Psychology of Voting. In Information-WahrnehmungEmotion: Politische Psychologie in der Wahl- und Einstellungsforschung, ed. T. Faas, K. Arzheimer, and S. Roßteutscher, 13-31. Wiesbaden: VS Verlag.

Thomson, M. 2006. Human Brands: Investigating Antecedents to Consumers' Strong Attachments to Celebrities. Journal of Marketing 70(3): 104-119.

Trump, D. 2017. Donald Trump Inauguration Speech Full Transcript. Retrieved December 12, 2019 from Belfast Telegraph. https://www.belfasttelegraph.co.uk/news/world-news/donald-trump-inaugurati on-speech-full-transcript-35386639.html.

Tulis, J. 1987. The Rhetorical Presidency. Princeton, NJ: Princeton University Press.

Verser, R., and R.H. Wicks. 2006. Managing Those Impressions: The Use of Images on Presidential Candidate Web Sites During the 2000 Campaign. Journal of Communication 56(1): 178-197.

Volle, J.J. 2015. Twenty-Five Years of GOP Presidential Nominations: Threading the Needle. Basingstoke: Palgrave Macmillan.

Wang, C.H. 2013. Why Do People Vote? Rationality or Emotion. International Political Science Review 34(5): 483-501.

Wattenberg, M.P. 2016. The Declining Relevance of Candidate Personal Attributes in Presidential Elections. Presidential Studies Quarterly 46(1): 125-139.

Wilson, J.H. 1992. Herbert Hoover: Forgotten Progressive. Long Grove, IL: Waveland Press.

Winchester, T., J. Hall, and W. Binney. 2016. Conceptualising Usage in Voter Behaviour for Political Marketing: An Application of Consumer Behaviour. Journal of Political Marketing 15(2-3): 259-284.

Winter, D.G. 1998. A Motivational Analysis of the Clinton First Term and the 1996 Presidential Campaign. The Leadership Quarterly 9(3): 367-376.

Dr. Neil Collins is Emeritus Professor of Government at UCC. He is currently also Professor of Political Science, Nazarbayev University, Kazakhstan. 